\begin{tabular}{|l|l|l||}
\hline \multicolumn{2}{|c|}{ PublisherInfo } \\
\hline \hline PublisherName & $:$ & BioMed Central \\
\hline \hline PublisherLocation & $:$ & London \\
\hline \hline PublisherImprintName & $:$ & BioMed Central \\
\hline \hline
\end{tabular}

\title{
PPAR-? ligands suppress arthritis in rats
}

\begin{tabular}{|l|l|l||}
\hline \multicolumn{2}{|c||}{ ArticleInfo } \\
\hline \hline ArticleID & $:$ & 145 \\
\hline \hline ArticleDOI & $:$ & $10.1186 /$ ar-2000-66851 \\
\hline \hline ArticleCitationID & $:$ & 66851 \\
\hline \hline ArticleSequenceNumber & $:$ & 102 \\
\hline \hline ArticleCategory & $:$ & Paper Report \\
\hline ArticleFirstPage & $:$ & 1 \\
\hline \hline ArticleLastPage & $:$ & 3 \\
\hline \hline & & RegistrationDate : 2000-9-28 \\
\hline ArticleHistory & $:$ & OnlineDate \\
\hline \hline ArticleCopyright & $:$ & Current Science Ltd2000-9-28 \\
\hline \hline ArticleGrants & $:$ & \\
\hline \hline ArticleContext & $:$ & 130753311 \\
\hline \hline
\end{tabular}


Aff1 Johns Hopkins University Medical School, Baltimore, MD, USA

\section{Keywords}

Adjuvant-induced arthritis, apoptosis, PPAR-? ligands

\section{Context}

Peroxisome proliferator-activated receptors (PPARs) are ligand-activated transcriptional factors of nuclear hormone receptor super family with some immunomodulatory properties. Various lipid or prostaglandin molecules have been proposed as natural PPAR-? ligands. Recent studies have shown that the PPAR-? ligands $15 \mathrm{~d}-\mathrm{PGJ}_{2}$, and troglitazone (a synthetic anti-diabetic) induce apoptosis in various cell types and inhibit nitric oxide (NO), tumor necrosis factor (TNF)-a, interleukin (IL)-1?, and IL-6 synthesis by antagonizing the activities of AP-1 and NF- B transcription factors. Therefore, the authors investigated the expression of PPAR-? in synovial tissues and in cultured synoviocytes of rheumatoid arthritis (RA) patients.

\section{Significant findings}

PPAR-? expression was detected in synovial tissues of all RA and OA patients in RA patients the expression was marked in macrophages and moderate in synovial cells, endothelial cells, and fibroblasts. The expression was lower in cells from OA patients. Untreated cultured synoviocytes showed both cytoplasmic and nuclear expression but $15 \mathrm{~d}-\mathrm{PGJ}_{2}$ treated cells showed nuclear translocation of PPAR-?. PPAR? mRNA and protein were produced by synoviocytes of RA patients and detected using RT-PCR and western blot analysis. PPAR-? ligands, troglitazone and 15d-PGJ 2 effectively inhibited synoviocyte proliferation and induced classic apoptotic changes in these cells. Intraperitoneal administration of $15 \mathrm{~d}-\mathrm{PGJ}_{2}$ and troglitazone ameliorated AIA in Lewis Rats, suggesting that PPAR-? ligands have ani-inflammatory and growth-inhibitory effects on synovial cells without obvious side effects.

\section{Comments}


Several inflammatory mediators (prostaglandin E2, cytokines, and nitric oxide) are involved in the pathogenesis of rheumatoid arthritis (RA). Understanding the molecular mechanisms by which these inflammatory molecules mediate the pathogenic process is important for designing therapeutic interventions. The present study elegantly demonstrates the presence of PPAR-? in the synovial tissues from RA patients. More importantly they show that the PPAR-? ligands 15 -deoxy-? ${ }^{12,14}$-prostaglandin $\mathrm{J}_{2}\left(15 \mathrm{~d}-\mathrm{PGJ}_{2}\right)$ and thiazolidinedione (troglitazone) induce apoptosis in RA synoviocytes in vitro.

Furthermore, treatment with $15 \mathrm{~d}_{-} \mathrm{PGJ}_{2}$ and thiazolidinedione significantly improves symptoms in an adjuvant-induced arthritis (AIA) Lewis rat model without significant side effects. The precise mechanism of action of these agents needs to be studied in more detail.

\section{Methods}

Synovial tissues from RA and osteoarthritis (OA) patients were used. Synovial tissues and cultured cells from these tissues were immunostained with anti-human PPAR- and the extent and intensity of staining was graded on various cell types. The PPAR- mRNA and protein expression was studied by RT-PCR and Western blotting. The cell proliferation and growth-inhibitory activities were studies by MTT assay. Apoptosis in cultured synovial cells was detected by Hoechst staining and propidium iodide. Female Lewis rats were used for arthritis induction and 15d-PGJ 2 or troglitazone treatment.

\section{References}

1. Kawahito Y, Kondo M, Tsubouchi Y, Hashiramoto A, Bishop-Bailey D, Inoue K, Kohno M, Yamada R, Hla T, Sano H: 15-deoxy-? ${ }^{12,14}$-PGJ 2 induces synoviocyte apoptosis and suppresses adjuvant-induced arthritis in rats. J Clin Invest. 2000, 106: 189-197.

This PDF file was created after publication. 